\title{
The Determinants of Household Poverty in South Africa
}

OBI Ajuruchukwu | TAFA Sanelise

\section{Abstract}

South Africa was privileged to be part of the MDGs agenda which was adopted in 2000. One of the aims of MDGs was to reduce extreme poverty by half in 2015 . For that reason, South Africa integrated policies and strategies to rid poverty by half to that of United Nations (UN). Through all the combined policy approaches, South Africa has successfully achieved the target of halving the population living below PPP\$1.25c per person per day. Whichever threshold used, the results showed that the percentage share of people living below poverty line has now decreased from 11.3 per cent in 2000 to 4.0 per cent in 2011. However, these reports are not reflecting the exact poor's experiences because at household level there is still an outright poverty.
Therefore, if the national poverty report gives a good picture about South African poverty status whereas there is still prevalence of poverty at household level, there are high chances that wrong policies in regard to poverty reduction strategies will be wrought. Hence this paper focuses on the determinants of household poverty in South Africa. The sole aim of this paper is to assess the determinants of household poverty in South Africa. The reviewed literature on determinants of poverty in South Africa would enable policy makers to see the effect of demographic characteristics on poverty in South Africa. Thus, strategies and policies aimed at alleviating poverty in South Africa can be directed to the discussed factors.

Keywords: Poverty, Millennium Development Goals, Absolute poverty, Relative poverty 


\section{Introduction}

In the year 2000, leaders from 189 different countries held a meeting which resulted into eight goals which were termed Millennium Development Goals (MDGs). One of the goals was to rid extreme poverty by half in 2015 (Lihohla, 2013). These leaders knew that the challenge of poverty is faced by both the developing and the developed world, although it is more prevalent in Africa (Sekhampu, 2015). For that reason, South Africa integrated policies and strategies to halve poverty by 2015 .

Policies aimed at reducing poverty fully depend on how it is measured and defined (Sekhampu, 2013). Poverty definition will in turn bring an understanding on the causes of poverty and the strategies that can be adopted in order to reduce it. Understanding of what poverty is thereof will emphasise the appreciation of the difficulties and serves as a reminder that searches for strategies of poverty reduction.

In South Africa there seems to be disparity on how the national poverty is defined compared to the household poverty. For example, all poverty measures used in South Africa reveal that the percentage share of people living below poverty line has now decreased from 11.3 per cent in 2000 to 4.0 per cent in 2011 (Lihohla, 2013). Moreover, South Africa is regarded as the upper-middle income country with approximately $\$ 13,300$ of GDP per capita. Furthermore, Lihohla (2013) stated that the progress reports on MDGs (2005, 2010 and 2013) recorded that the country has managed to reach the global and national goal of reducing poverty levels and hunger by half.

However, these reports are not reflecting the exact poor's experience. For example, Meyer (2014) argued that there is still prevalence of poverty in many South African households. Moreover, some of the perceived major causes of poverty such as income inequality, unemployment rate have increased since the transition from the apartheid system to the democratic system. Moreover, land ownership and educational attainment has worsened.

Now the MDGs period has come to an end, with success claims which are not reflected by those who are in poverty. Therefore, there is a possibility that wrong poverty reduction strategies will be derived and implemented. As the Sustainable Development Goals (SDGs) are starting with one of the goals of ending poverty anywhere and everywhere by 2030 and create euphoria of complexity at local level in place (Olsen et al,, 2014), having in mind, the revised \$1.90c PPP ratio of September 2015, it is an opportune time to conceptualise the problem. 
The objective of this paper is to assess the determinants of poverty in South Africa. The reviewed literature on determinants of poverty in South Africa would enable policy makers to see the effect of demographic characteristics on poverty in South Africa. Thus, strategies aimed at alleviating poverty in South Africa can be directed to the discussed factors.

This paper is organized as follows: after this section which has given an introduction, the following section, which is section 2, shall provide a brief review of the literature on poverty measurers used in South Africa. In addition, an overview of poverty status in South Africa and an overview on the South African economy are also presented in section 2. Section 3 discusses the determinants of poverty in South African households. Finally, the $4^{\text {th }}$ section concludes the study highlighting some policy implications for poverty reduction strategies and policy.

\section{Conceptualisation of poverty}

Academic literature interchanges the use of concepts of poverty and its definition, howbeit; this paper will not do so, because it has been found confusing (Richmond, 2007). Hence forth, this paper differentiates definition, measurement of poverty and poverty concepts. As Lister (2004) once said:

The policies developed to tackle poverty reflect dominant conceptualisations. In practice, concepts are mediated by definitions and measures and it is important to differentiate between the three as they are frequently conflated. Thus for instance, 'concept' and 'definition' are often used interchangeably. A clearer separation between the three terms helps to avoid confusion and unnecessary confusion between broader and narrower notions of poverty.

There are two important frameworks normally used for poverty conceptualising, namely, "absolute and relative" approaches.

Absolute poverty is whereby an individual's basic needs are not met ( $\mathrm{L}$ de, 2006). Basic needs include food, clothes, housing, etc. Richmond (2007) stated that absolute poverty talks about families whose monthly earnings are not enough to obtain the minimum necessities of the individual. Hence, in it is the basis of the development of food poverty lines. However, food poverty lines are only based on calculations of the income needed to meet the required human requirements such as keeping people alive without taking into 
consideration of other human needs. Hence, Liu and Wu (1998) criticised this approach stating that human needs are not only based on physical needs rather also based social needs. Moreover, people are created to be social beings with a role of being active citizens and fully depended on public provided utilities and facilities.

Relative poverty is a concept closely linked to the inequality notion. A person is reflected as poor when they are either socially, financially disadvantaged compared to other people in their society or environment ( $L$ de, 2006). This concept links poverty to a particular point in the distribution curve of an agreed upon variable such as income.

However, according to Liu and Wu (1998) measuring poverty using either relative approach can be deceiving sometimes; this approach always perpetuates poverty in some statistical sense and regards a certain proportion of people as poor without bringing their means of living. Hence the government lacks the necessary information on the actual amount of assistance the surviving poor families need in order to reach the recommended standards of living (Liu \& Wu, 1998).

\section{Definition of poverty}

An international debate about who is in the best position to define poverty has not yet ended (Richmond, 2007). The heating questions are; is it best achieved by those who are the experts or by ordinary people who experience poverty at first hand?

\section{Views of the poor on poverty}

Poverty is beyond income (Nelson \& Prilleltensky, 2010). When it comes to poor people, wellbeing is multidimensional with two dimensions, viz. material and psychological. Wellbeing means to have a peace of mind with good health, belonging to a community with dependable income accompanied by guaranteed safety and freedom of choice and action (Nelson \& Prilleltensky, 2010).

Describing the opposite of wellbeing which is ill-being, the poor see it as a "lack of basic needs" (such as food, clothing, house, etc.) and a healthy working environment (Nelson \& Prilleltensky, 2010). These are the following voices of the poor when defining poverty according to their daily lives experiences:

"One farmer's family has worked for a family for three generations, hard physical labour every day. This man has worked since his birth for the same 
farmer but has nothing, no savings, not even a bicycle. These people can afford nothing but survival." - South Africa 1998

"I sold my land and now I have nothing. I can never buy my land back because the prices go up every year." - Tanzania 1997

"We are all farmers in this village. When two farmers cultivate together the same plots and at the end of the harvest season, one has made a profit that allows him to get a lot of things and the other hasn't earned a thing, they will say that the second farmer is poor. But next year it could be the reverse. The fact is that we are all poor in this village." - Togo 1994

"The prosperity of our village has increased. Before, the two tribes in our village used to be divided. Now they belong to the same group, which brings them together. No two people have the same intelligence or resources, so when people come together they can solve many problems." - Tanzania 1997

"If I had gone to school, I would have got a job and I would have obtained a husband who has a salaried job." - Uganda 1998

"Poverty is because of the land; the person who doesn't have any must obligatorily leave to do day labour." - Ecuador 1996

"We have neither land nor work... Some of us have land in the reserve, but we can't transport our products from there because it is too far. It is difficult to carry them, and since I don't have land here, and only in the reserve, I am poor." - Ecuador 1996

"We think the earth is generous; but what is the incentive to produce more than the family needs if there are no access roads to produce to a market?" — Guatemala 1997

"Without these simple humane signs of solidarity, our lives would be unbearable." - A poor woman, Ukraine 1996

"The rich are those who are able to save and sell part of their harvest when prices rise." - A poor man, Niger 1996 
"Poverty is lack of freedom, enslaved by crushing daily burden, by depression and fear of what the future will bring. "- Georgia 1997

"The rich have one permanent job; the poor are rich in many jobs." - Poor man, Pakistan

"In the evenings, eat sweet potatoes, sleep. In the mornings, eat sweet potatoes, work. At lunch, go without." - A poor man from Vietnam 1999

"When I leave for school in the mornings I don't have any breakfast. At noon there is no lunch, in the evening I get a little supper, and that is not enough. So when I see another child eating, I watch him, and if he doesn't give me something I think I'm going to die of hunger." - A 10-year-old child, Gabon 1997

Source: From the World Bank's, Can Anyone Hear Us?

Voices from 47 Countries' publication: (from the website: "http://siteresources.worldbank.org/INTPOVERTY/Resources/335642-

1124115102975/1555199-1124115187705/vol1.pdf")

From the above list of voices from the poor, it can be deduced that poverty is multidimensional. This is to say, poverty never results from one thing. Moreover, it also varies depending on gender, culture, social economic context, age, etc. To summarise the poor's view on poverty definition from the first person cited as from South Africa, poverty is being vulnerable within the household and on the job. The characteristics of vulnerable are solely dependence and lack of one's own resources (Narayan et al., 2000).

The second poor person implies that being poor is lack of assets. Narayan et al. (2000) stated that lack of asset brings fear and anxiety about future and environmental uncertainties. This definition is closely linked to the one mentioned by a poor person from Togo in 1994. Farmers are always facing shocks and decline in food prices due to seasonal fluctuations.

Although nowadays, capitalist system is increasing, poor people still define poverty in relation to social capital, of which it is simply defined as the benefits of membership within an organised social network (Narayan et al., 2000). Poor people believe that if one has access to additional resources through a certain connection, he/she cannot be poor. 


\section{Views of the experts on poverty}

Globally, poverty remains a social problem due to its effect on less food. Scholarly articles on poverty have come up with a range of definitions. However, the over-emphasized thread is identifying what important goods a human being would require in order to survive (Richmond, 2007). Moreover, another thread in poverty discourse is the idea of lacking necessary resources for human survival. However, basing the definition of poverty on these ideas might be misleading because some people are surviving but still regarded as poor (Richmond, 2007).

\section{Poverty line}

According to Richmond (2007), poverty line was first used to quantify levels of poverty in an attempt to separate those who are poor from the non-poor. Lehohla (2011) puts it in this way, as a "... line which establishes a minimum socially accepted standard for a certain predetermined welfare indicator in order to separate those who are poor from the nonpoor". The variation of the intensity of poverty among the poor brought the idea of multiple poverty lines, namely "Poverty Line (FPL), Lower Bound Poverty Line (LBPL), and Upper Bound Poverty Line (UBPL)".

\section{Inequality}

The Gini coefficient [is] a global tool that "measures the extent to which the distribution of income" within the society and the economy deviates from an equal distribution and ranges between 0 and 1 , with 0 representing the complete equal society and 1 representing the complete unequal society (Hamse, 2013). Inequality measured can be two fold; i.e. Income inequality and wealth inequality (Bosch et al., 2010). Wages, rental, interest and profits which are received monthly all refer to an income, while wealth is made up of household assets from savings.

Although moderate levels of inequality might be tolerable in order to incentivise people to work harder and study, high levels of inequality suppresses the impact of economic growth (Hamse, 2013). Therefore, to be on a safer side, a country should range between 0.25 and 0.4 (Hamse, 2013). 


\section{Overview of South African economy}

The advent of democracy brought a substantial transformation to the South African economy (IDC, 2013). The records reveal that between 1994 and 2012, the economy grew at 3.3\% per annum in real terms (IDC, 2013), howbeit; growth has been quite volatile and strongly affected by the global economic performance as shown in Figure 1. The global recession between 2007 and 2008 brought a global downturn, howbeit, South Africa's strong anchors made it resilient in the first phase of the global recessional turmoil (Kganyago, 2012). For that reason, the former Finance Minister of South Africa, Trevor Manual declared South Africa as a free country from global economic crash citing the past experience of the late 1990s. In late 1990s, South Africa little weathered from the Asian financial turmoil because of the soundness of the structural adjustment programmes and the Growth, Employment and Redistribution program (GEAR) (Padayachee, 2010). The challenge faced by the South African Reserve Bank was to control inflationary pressures coming from the oil prices (Viegi, 2008).

\section{Figure 1}

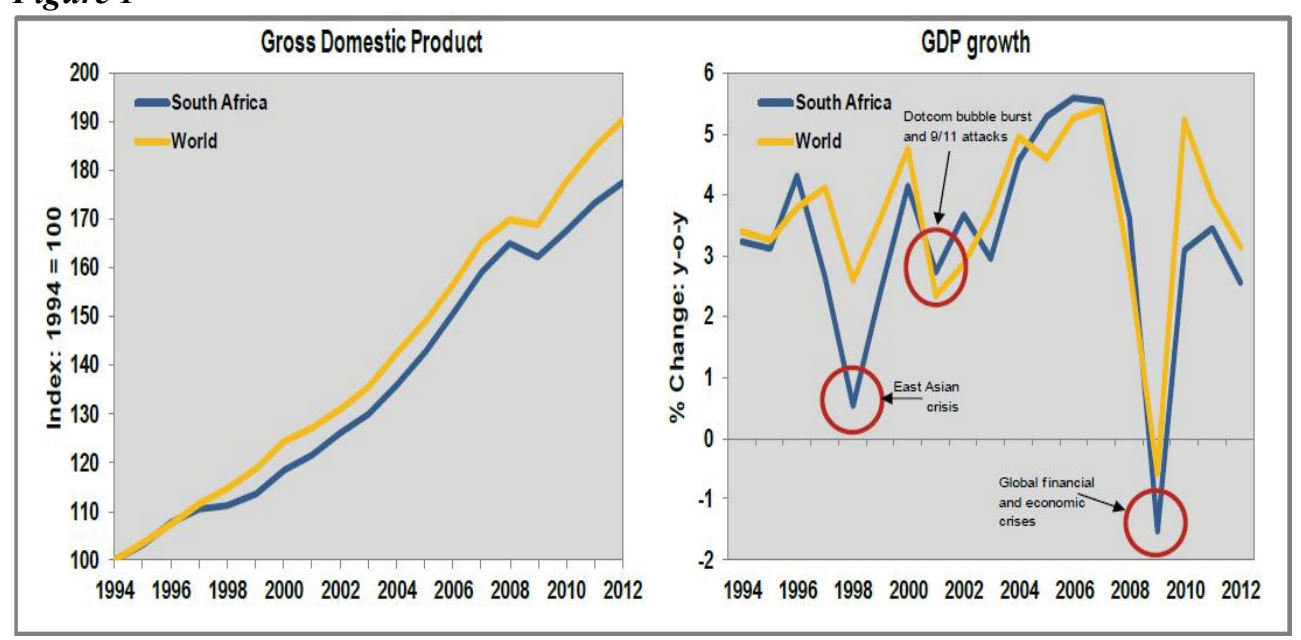

Source: IDC, 2013

From June to July of 2008, the situation changed for South Africa. International capital flows stopped and produced a collapse of share prices and exchange rate (Viegi, 2008). The JSE stock exchange devalued by $20 \%$ in the third quarter of the year and has resulted to a 37\% Rand Depreciation against US dollar (Viegi, 2008). Moreover, the lower liquidity 
of European and Japanese market negatively impacted on the Rand dominated (denominated?) bonds (Padayachee, 2010).

However, comparing South African real GDP within the BRICS quintet, the growth rate has not realised higher growth parallel to the world average, as shown in Figure 2.

Figure 2

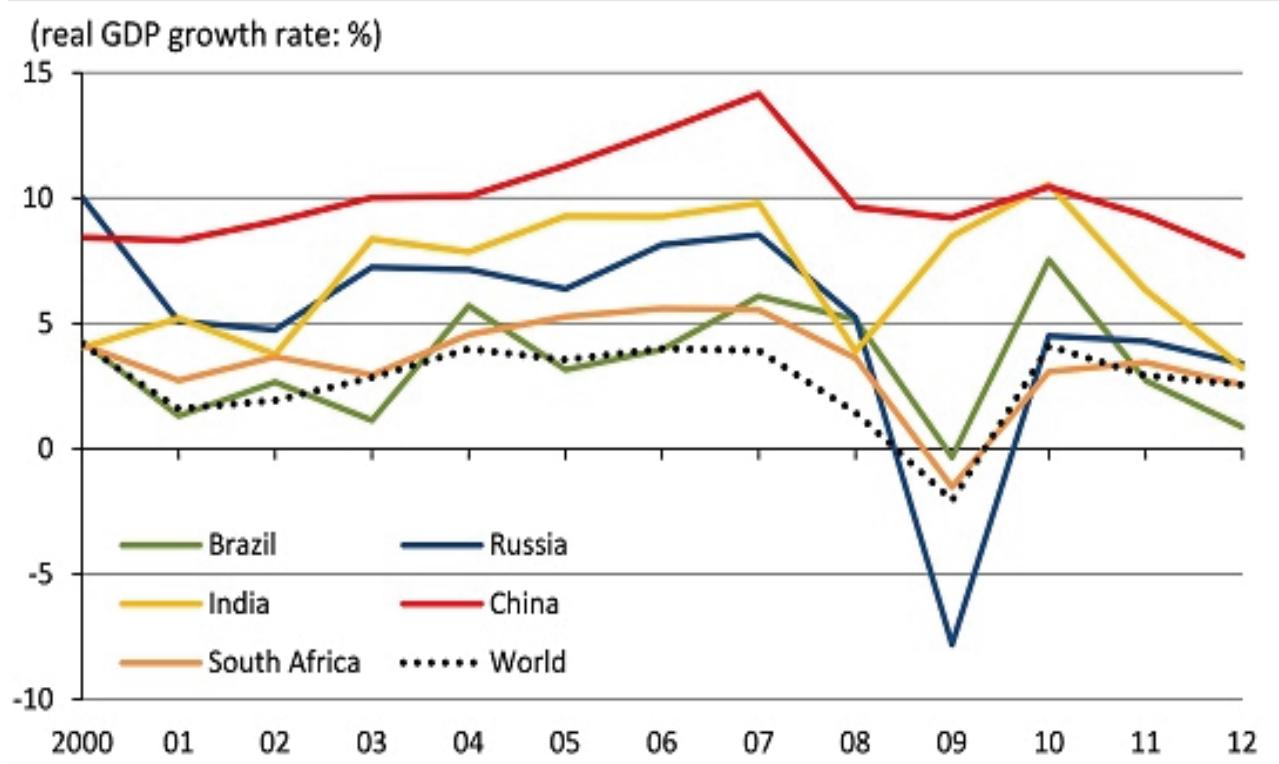

Source: Egawa, 2014

All BRICS economies, save South Africa and Brazil, grew at a faster rate since the inception of the BRICS idea. According to Gumede (2015), one of the major challenges to the South African economy is lack of a clear and consistent policy. For example, while GEAR framework was bringing a significant impact to stabilising the economy since 1996, it fell apart. Furthermore, ASGISA programme (adopted in 2005) which was still in play was shortlived by bringing NGP which was overtaken by NDP prematurely. Gumede (2015) stated that even though NDP is a current renowned policy in South Africa, it does not address structural challenges facing the South African economy. 


\section{Unemployment rate}

One of the biggest challenges among the others faced by the post-apartheid government in South Africa is the mass unemployment (IDC, 2013). Since then, the South African economy has not been able to generate sufficient employment opportunity for the positively growing labour force (IDC, 2013). In this period, about 3.4 million net new jobs were created (Netshitenzhe, 2013). Out of 3.4 million created jobs, 25.2 percent of labour force still remains unemployed, (World Bank, 2012). Despite the up and downturns of official unemployment rate which once peaked up 31.2 per cent in 2003 and dropped to 23 per cent in 2007, people are still zealous looking for jobs (Netshitenzhe, 2013). Diverse factors such as mismatch of skills between employers' requirements and available skills, imbalances between wage costs and productivity etc., have contributed to the poor contribution of the economy on employment.

\section{Land ownership in South Africa}

South African land ownership before 1994 presented inequality pattern (Hall et al., 2003). It is noted that white farmers owned up to $87 \%$ farmland (Slorstad, 2010). Note that, white population was up [to] $20 \%$ in South Africa by that time and black population was up to 80 per cent and they were living in land of about $13 \%$ of South Africa (Kahn, 2007).

This happened as the result of 1913 Land Act which was followed by a huge disposition (Kahn, 2007). The result was that 82 million hectares of land was possessed by sixty thousand white farms (Khan, 2007). On the other hand 16375435 hectares was the only land given to black owners from the total land area of 122 million hectares in South Africa (Pringle, 2013).

This produced a widespread of rural poverty in South Africa (Hall et al., 2003). Kahn (2007) added that the vast inequality caused majority of the country to live in poor conditions which led to high infant mortality and illiteracy became a norm. One of the reasons for majority of problems that bedevilled the blacks is that the land owned by the whites included all metropolitan land, national forests, aquatic catchment areas, flora and fauna reserves, regional reserves and state parks (Pringle, 2013).

Most blacks whether in urban or rural areas have a belief that land was stolen (Atuahene, 2013). Their belief leads them to claim it back by force whether the result might be political unrest or not (Atuahene, 2013). Hence, land reform programme was initiated. 
According to World Bank (1975), land reform refers to the institutional changes governing man's connection with land. Land reform focuses on restructuring arable land Beehner (2005). The restructuring focuses on both collectivised land by the state or held by rich farmers Beehner (2005).

Boyce et al. (2005) stated that the reason behind these changes of laws is to establish a more equitable distribution of farmland. The other reason is that the landless, tenants and farm workers may have a benefit in the land Adam (1995). Besley and Burgess (1999) stated that this benefit in the land is meant improve poor's access to land; in order to lessen poverty that is so prevalent (Ahmed, 2014).

Obeng-Odoom (2011) stated that certifying women's rights was the fundamental aim of the land reform and many policies were implemented to achieve that aim; Ensure that South Africans, especially the poor, women and the youths have a rational opportunity to gain contact to land with secure rights (African National Congress, ANC, 2012). To achieve the debated aims, the South African government targeted that by the year 2014 thirty per cent of white-owned land has to be distributed back to the previously deprived people through land tenure reform, redistribution, and restitution (Wachter, 2010).

Through ups and downs, in 2008, the true extent of land transferred from white to black owners was close to $6.8 \%$ of commercial agricultural land of which $47 \%$ has been transferred through state action (Centre of Defence Enterprise, CDE, 2008). The true figure currently is $8 \%$ of land bought since 1994 (Ndlozi, 2014).

\section{Education}

Currently, the government of South Africa is said to spend about $6.5 \%$ of the national Gross Domestic Product (GDP) on education, making an average of $20 \%$ of its national budget (Provincial Budgets and Expenditure Review, 2010). These figures have led the former apartheid-era foreign affairs minister to claim that South Africa has the highest per capita education expenditure in Africa (Moreo, 2015). For example, when comparing with neighbouring countries such as Zimbabwe, which spends just R18 a month per child, the South African Education Department spends about R2 000 a month per child. Moreover, in 2007 South Africa was spending about US $\$ 1,225$ on primary education per pupil while Kenya spends only US $\$ 258$ on primary education per pupil.

However, when comparing South Africa in the Southern and Eastern Africa Consortium for Monitoring Educational Quality (SACMEQ) with other countries such as Botswana, 
Kenya, Lesotho, Malawi, Mauritius, Mozambique, Namibia, Seychelles, Swaziland, Tanzania, Uganda, Zambia and Zimbabwe, South Africa's average student reading score placed it $10^{\text {th }}$ out of 15 countries (Wilkinson, 2013). Moreover, in the third SACMEQ research project which had 10 countries such as "Kenya, Lesotho, Malawi, Namibia, Swaziland, Tanzania, Uganda, Zambia, Zimbabwe and South Africa", South Africa was found to be underperforming.

It has been found perplexing to see that the budget which is allocated to the Department of Education is increasing but the South African pupils' performance compared to other neighbouring countries is very low. Due to the fact that this paper mainly focuses on the determinants of poverty in South Africa, not on the challenges faced by the South African education system, we stick to the objective of the paper. This is a research gap for academia.

\section{Determinants of poverty}

Empirically, there is a vast literature which discusses the factors that contribute to an individual's poverty status. The majority of these studies have looked at the demographic characteristics of a household. Sekhampu (2013) stated that age, gender, education level of a household head, household size, and employment status or unemployment rate are very important for consideration when coming with the poverty alleviation strategies.

Table 1: difference between poor and non-poor households

\begin{tabular}{|l|l|l|l|}
\hline & Poor & Non-poor & Overall \\
\hline Mean household size & 4.8 & 2.9 & 3.9 \\
\hline Mean household Age & 21.9 & 30.1 & 26.2 \\
\hline Household Head Mean Education & 6.0 & 9.3 & 8.2 \\
\hline Unemployment Rate & $53.6 \%$ & $19.7 \%$ & $31.1 \%$ \\
\hline
\end{tabular}

Source: Argent et al., 2009 
i. Distribution of the relationship between poverty and households size in South Africa

The household size presented in Table 1 can be described as a sum of people that are sharing the means of shelter, food and the same sources of livelihood. Weldegiorges (2014) defined resident members as those who have lived for at least half a year or six months in the previous 12 months. Therefore, household size includes both young and old, i.e., children, parents, grandparents, and any other persons who have joined the family to live permanently or for a specified period.

The relationship between poverty and household size can either be positive or negative, depending on the level of modernisation in the country (Windyanti et al., 2009). In less developed countries, where agriculture is the powerhouse of the economy, larger households tend to have less poverty. Nevertheless, in modernised countries, where there is limited access to subsistence farming, larger households tend to experience poverty.

Meyer and Nishimwe-Niyimbanira (2016) stated that there is an unclear relationship between poverty and household size. This is because any economic change of the household could restructure household composition. For example, household economic condition can prompt the household to have large household size through bearing more children or through the external family members.

Table 1 reveals that the overall household size is 3.9 while the poor and nonpoor household size average is 4.8 and 2.9 respectively. These results are confirming World Bank's results from the 1995 paper entitled, 'Key Indicators of Poverty in South Africa'. The paper revealed that large households with many dependants are much more likely to be poor in South Africa. Schwabe (2004) stated that the large households require large income to keep family members out of poverty. For example Mbuli (2008) revealed that the average household size among the poor is 5.9, whereas among the reach it is only 3.5. Moreover, the highest dependency ratio is highest among the poor. 


\section{ii. Distribution of the relationship between poverty and age in South Africa}

Table 1 also presents the relationship between poverty and household head age, as taken from the literature. Table 1 reveals that high poverty is on the youth and adolescents (Mbuli, 2008). This is also confirmed by Malik (1996) study whereby he argued that households whose head are higher in age have the lowest possibility of becoming poor. This is due to youth's reliance on adults for provision of basic needs.

However, Baiyegunhi and Fraser (2010) argued that household headed by old age people are more vulnerable to poverty than those headed by younger people. Baiyegunhi and Fraser (2010) further explained that this could be due to the fact that the majority of older people have to fend for themselves, of which most of the time they do not have anyone to support them through remittances.

iii. Distribution of the relationship between poverty and low levels of education in South Africa

Different studies have come up with different opinions on the subject of relationship between poverty and education. Minot and Baulch (2005) stated that the number of years spent in schooling significantly reduce the probability of becoming poor. Table 1 shows that the overall number of years spent in education is 8.2 while those who are poor and non-poor spent 6.0 and 9.3 years in education, respectively. Relationship between poverty and level of education presented in Table 1 shows that poor households are also characterised by the low number of years at school. This confirms the study done by World Bank (2002) which concluded the same. Moreover, Baiyegunhi and Fraser (2010) emphatically stated that households are more vulnerable to poverty when the household head's education is low. Thus, explaining the significant negative coefficient to the incident of poverty reported by Baiyegunhi and Fraser's study conducted in 2014 in Amathole District Municipality in the Eastern Cape Province of South Africa. Mbuli (2008) argued that these people are mostly found in the Eastern Cape Province of South Africa. Moreover, Mbuli (2008) further stated that in 1998, the figures were as follows: " $58 \%$ of adults with no education were poor; $53 \%$ of adults with less than seven years of education were poor; $34 \%$ of adults with incomplete secondary schooling were poor; $15 \%$ of adults who had completed 
secondary school were poor; and only $5 \%$ of adults with tertiary education were poor."

However, this is not always true, for example, the study conducted by Sekhampu (2013) titled, 'The determinants of poverty in South African Township', revealed that there is no significant relationship between education level and poverty level in South African townships. The results were further explained that the years spent on schooling might not fully explain poverty.

iv. Distribution of the relationship between poverty and unemployment in South Africa

In South Africa, poverty and unemployment is said to have a strong correlation. Table 1 presented the relationship between poverty and unemployment. Unemployment rate is high among the poor compared to the non-poor, with $53.6 \%$ and $19.7 \%$, respectively. This was also seen by Woolard (2002) in his study, which reported that the unemployment rate is about $52 \%$ among the South African poor while the national unemployment rate was $29 \%$. Moreover, non-poor households have greater contribution to labour in South Africa compared to the poor.

\section{v. Distribution of the relationship between poverty and race in South Africa}

Although poverty is not confined to one racial group in South Africa, it is more concentrated among the Africans. For example, Gradin (2013) stated that $30 \%$ of the black population in 2008 lived in traditional or informal dwellings, while $66.67 \%$ lacked piped water inside their homes, compared with 0.5 and $5.5 \%$ of whites, respectively. 
Table 2: Racial poverty gap

Income Poverty

\begin{tabular}{lccccccc} 
& Pop. Share & \multicolumn{3}{c}{ Poverty Measure } & \multicolumn{3}{c}{ Poverty Shares } \\
& & $\mathrm{P}_{0}$ & $\mathrm{P}_{1}$ & $\mathrm{P}_{2}$ & $\mathrm{P}_{0}$ & $\mathrm{P}_{1}$ & $\mathrm{P}_{2}$ \\
\hline African & $79.3 \%$ & $56.1 \%$ & $26.0 \%$ & $15.5 \%$ & $94.0 \%$ & $95.4 \%$ & $96.0 \%$ \\
Coloured & $8.9 \%$ & $27.4 \%$ & $9.9 \%$ & $4.9 \%$ & $5.2 \%$ & $4.1 \%$ & $3.4 \%$ \\
Asian/Indian & $2.6 \%$ & $8.5 \%$ & $1.8 \%$ & $0.8 \%$ & $0.5 \%$ & $0.2 \%$ & $0.2 \%$ \\
White & $9.2 \%$ & $1.5 \%$ & $0.8 \%$ & $0.6 \%$ & $0.3 \%$ & $0.3 \%$ & $0.4 \%$ \\
Overall & $100 \%$ & $47.3 \%$ & $21.6 \%$ & $12.79 \%$ & $100 \%$ & $100 \%$ & $100 \%$ \\
\hline
\end{tabular}

Expenditure Poverty

Pop. Share Poverty Measure Poverty Shares

\begin{tabular}{lccccccc} 
& & $\mathrm{P}_{0}$ & $\mathrm{P}_{1}$ & $\mathrm{P}_{2}$ & $\mathrm{P}_{0}$ & $\mathrm{P}_{1}$ & $\mathrm{P}_{2}$ \\
\hline African & $79.3 \%$ & $62.8 \%$ & $31.5 \%$ & $19.0 \%$ & $93.5 \%$ & $95.5 \%$ & $96.4 \%$ \\
Coloured & $8.9 \%$ & $31.7 \%$ & $11.9 \%$ & $5.8 \%$ & $5.3 \%$ & $4.0 \%$ & $3.3 \%$ \\
Asian/Indian & $2.6 \%$ & $16.7 \%$ & $2.5 \%$ & $0.6 \%$ & $0.8 \%$ & $0.2 \%$ & $0.1 \%$ \\
White & $9.2 \%$ & $2.5 \%$ & $0.8 \%$ & $0.3 \%$ & $0.4 \%$ & $0.3 \%$ & $0.2 \%$ \\
Overall & $100 \%$ & $53.3 \%$ & $26.2 \%$ & $15.6 \%$ & $100 \%$ & $100 \%$ & $100 \%$ \\
\hline
\end{tabular}

\section{Source: Gradin, 2013}

vi. Distribution of the relationship between poverty and gender in South Africa Baiyegunhi and Fraser (2014) stated that there is a statistical significance, although the relationship is negative, between gender and the incidence of poverty. Meaning that female headed households are more likely to be poor compared to the male headed households. 
Table 3: Differences in poverty on household gender

\begin{tabular}{|l|c|c|c|c|c|c|c|c|c|}
\hline \multicolumn{5}{|c|}{ Individuals } & \multicolumn{5}{c|}{ Households } \\
\hline & $\begin{array}{c}\text { Poverty } \\
\text { line } \\
\text { R577 }\end{array}$ & $\begin{array}{c}\text { Poverty } \\
\text { line } \\
\text { R416 }\end{array}$ & $\begin{array}{c}\text { Poverty } \\
\text { line } \\
\text { R305 }\end{array}$ & $\begin{array}{c}\text { Poverty } \\
\text { line } \\
\text { R142 }\end{array}$ & & $\begin{array}{c}\text { Poverty } \\
\text { line } \\
\text { R577 }\end{array}$ & $\begin{array}{c}\text { Poverty } \\
\text { line } \\
\text { R416 }\end{array}$ & $\begin{array}{c}\text { Poverty } \\
\text { line } \\
\text { R305 }\end{array}$ & $\begin{array}{c}\text { Poverty } \\
\text { line } \\
\text { R142 }\end{array}$ \\
\hline Men & .46 & .36 & .264 & .07 & $\begin{array}{l}\text { Male- } \\
\text { headed }\end{array}$ & .33 & .23 & .15 & .03 \\
\hline Women & .57 & .46 & .342 & .09 & $\begin{array}{l}\text { Female- } \\
\text { headed }\end{array}$ & .55 & .43 & .31 & .07 \\
\hline Total & .52 & .42 & .31 & .08 & Total & .43 & .32 & .22 & .05 \\
\hline $\begin{array}{l}\text { Gender } \\
\text { poverty } \\
\text { ratio }\end{array}$ & $1.23 *$ & $1.28 *$ & 1.30 & 1.34 & $\begin{array}{l}\text { Gender } \\
\text { poverty } \\
\text { ratio }\end{array}$ & $1.69 *$ & $1.91 *$ & $2.07 *$ & $2.12 *$ \\
\hline
\end{tabular}

Source: Rogan, 2014

There is a strong gender dimension to a South African poverty. Hence, there are varieties of poverty levels among the two genders, i.e. male and female. Table 3 presents households and individual poverty lines. Table 3 shows that both individually and as a household, women have the highest poverty rate compared to men using the three different poverty lines.

HDR (2003) reported that about 50.9\% of the poor in South Africa were poor females, while 45.9\% were males. Moreover, Mbuli (2008) stated that in 1998, about 60\% poor people from South Africa were females while it was just about $31 \%$ male headed household which was poor. Moreover, Woolard (2002) reported male headed households had 28\% chances of being poor while female headed households had $48 \%$ chances of being poor.

vii. Distribution of the relationship between poverty and lack of access to basic services in South Africa

According to Mbuli (2008), households owned by poor people normally lack access to basic services. However, Gradin (2013) argued that the advent of democracy increased the access of many poor South Africans to basic services such as electricity, taps, toilets, etc. although the fortune began with the nonpoor. For example, about $75 \%$ of the non-poor had electricity while the only about 27\% poor households had electricity in 1999 (Woolard, 2002). Moreover, 
Woolard (2002) further stated that about adequate sanitation was distributed to about $73 \%$ of the non-poor while to it was distributed to only about $38 \%$ of the poor. Finally, piped water was first given to about $77 \%$ of the non-poor while the distribution of piped water to the poor households was up to $47 \%$ (Woolard, 2002).

\section{viii. Physical asset (Land)}

According to Kambuli et al. (2008), the majority of the rural households are solely dependent on land for their livelihood strategies. Therefore, it is of paramount importance to improve the land tenure security in order that rural households can use their lands productively and sustainably. This is to say, land ownership should be promoted, and especially to those who till the soil because conditions that threaten access to land threaten livelihood strategies (Kambuli et al., 2008). For example, Sharma (1999) stated that incidence of poverty is also high in households with no land for subsistence production. Moreover, households that have no land ownership have limited access to credits. This is very painful for many rural people because much of the poor are found in rural areas and some of them derive their livelihood from farming but they do not own the land on which they are farming.

Although land is very important for alleviating poverty, the land reform progress report reveals that from 1995 to 2013, the state managed to redeem 4001 parcels of land (total size of $1.44 \mathrm{~m}$ ha) for restitution purposes and from the 77148 claims that have been settled (DA, 2013). However, most people preferred monetary compensation rather than land (Pepeteka, 2013). The people who preferred monetary compensation over land amounted to 92 per cent (Pepeteka, 2013). This leaves questions whether people see the significance of land for poverty alleviation.

\section{Conclusion and policy implication}

The asymmetric information between policy makers and the poverty status at both national and household level can be eliminated. It may, however, take time due to some complications within the poverty definition. However, looking at the household determinants of poverty will be of help. Among the discussed determinants of poverty, the relation between poverty, age, household size and education is uncertain. This is due 
to some factors within these determinants. For example, older people are the ones who are employed compared to the youth. Moreover, in some economies, where agriculture is the pillar with less modernisation, the larger households have a greater advantage when it comes to poverty alleviation strength compared to households with less number of people. Furthermore, although education is perceived to be the pillar which can be used to fight poverty in many societies, howbeit, this is not always true in South Africa. Some studies have revealed that there is a significant relationship between education and poverty, while others revealed otherwise results. This can be also deduced when comparing South African education and economy in relation to other African countries, such as Zimbabwe. This shows that poverty is also affected by the institutions. Good institutions can cater for both educated and uneducated.

As the SDGs are in their development stage, in order to set the policies that will be able to push poverty reduction strategies to wipe out every form of poverty in South Africa, it is better that they first tackle the determinants of poverty and thereafter use the multidimensional approach to measure poverty.

\section{List of References}

- Adams, M., 1995. Land Reform: New Seeds on Old Ground? Overseas Development Institute, Portland House, Stag Place, London.

- Ahmed, M., 2014. Inadequate Land Reforms Reason for Poverty and Social Unrest. Paper prepared for presentation at the "2014 World Bank Conference on Land and Poverty" The World Bank - Washington DC, March 24-27, 2014.

- $\quad$ ANC., 2012. Land reform policy discussion document. June, (2012), pp. 1 - 20.

- $\quad$ Argent, J., Finn, A., Leibbrandt, M. and Woolard, I., 2009. Poverty: Analysis of the NIDS Wave 1 dataset. National Income Dynamics Study, NIDS Discussion Paper, (12).

- Atuahene, B., 2013. South Africa's Land Reform Crisis. Foreign Affairs. Published by the Council of Foreign Relations. 
- Baiyegunhi, L.J.S. and Fraser, G.C., 2010, September. Determinants of household poverty dynamics in rural regions of the Eastern Cape Province, South Africa. In poster presented at the Joint 3rd African Association of Agricultural Economists (AAAE) and 48th Agricultural Economists Association of South Africa (AEASA) Conference, Cape Town, South Africa. Available

online: http://ageconsearch.umn.edu/bitstream/97078/2/63.\%20Poverty\%20dynamics\%20in\%20So uth\%20Africa.pdf

- Beehner, L., 2005. Q\&A: Land Reform. Council on Foreign Relations. Calvary August 1 Watch Trailer.

- Besley, T. and Burgess, R., 1999. Land Reform, Poverty Reduction and Growth: Evidence From India. Department of Economics, London School of Economics.

- Boyce, J.K., Rosset, P. and Stanton, A. E., 2005. Land Reform and Sustainable Development. Political Economy Research Institute. Working Paper Series No. 98.

- Democratic Alliance, DA., 2013. DA Policy on Land.

- Gradín, C., 2013. Race, poverty and deprivation in South Africa. Journal of African Economies, 22(2), pp.187-238.

- Hall, R., Jacobs, P. and Lahiff, E., 2003. Evaluating land and agrarian reform In South Africa. Programme for Land and Agrarian Studies. School of Government University of Western Cape.

- Harmse, L., 2014. South Africa's Gini coefficient: causes, consequences and possible responses. Available online: http://www.repository.up.ac.za/handle/2263/40181

- Industrial Development Corporation (IDC)., 2013. South African economy: An overview of key trends $\quad 1994 . \quad$ Available online: http://www.idc.co.za/reports/IDC\%20R\&I\%20publication\%20\%20Overview\%20of\%20key\%20trends\%20in\%20SA\%20economy\%20since\%201994.pdf

- Kahn, N., 2007. Land and Agrarian Reform in South Africa. Center for Policy Studies. Vol. 20(12), pp.8-45.

- L de, 2006. Poverty and its measurement: The presentation of a range of methods to obtain measures of poverty. Instituto Nacional de estatistica. Available online: http://www.ine.es/en/daco/daco42/sociales/pobreza_en.pdf

- Lehohla, P., 2011. Methodological report on rebasing of national poverty lines and development of pilot provincial poverty lines. 
- Lehohla, P., 2013. Millennium Development Goals: Country Report 2013.Government Gazette: Statistics South Africa.

- $\quad$ Lister, R., 2004. Poverty. Cambridge: Polity. Applied ethics and social problems, pp.715-728.

- Liu, E. and Wu, J., 1998. The measurement of poverty. Research and Library Services Division, Provisional Legislative Council Secretariat.

- Mbuli, B.N., 2008. Poverty Reduction Strategies in South Africa. Masters of Commerce Thesis: Economics, University of South Africa.

- Meyer, D.F. and Nishimwe-Niyimbanira, R., 2016. The impact of household size on poverty: An analysis of various low-income townships in the Northern Free State region, South Africa. Etude de la Population Africaine, 30(2).

- Meyer, D.F., 2014. The Impact of Housing and Basic Service Delivery on Low-Income Communities in South Africa: The Case of the northern Free State Region. Mediterranean Journal of Social Sciences, 5(13), p.11.

- Narayan, D., Schafft, K., Patel, R., Koch-Schulte, S., \& Rademacher, A., 2000.Can anyone hear us? Voices from 47 Countries. World Bank (Vol. I). World Bank Publications. Retrieved from http://elibrary.worldbank.org/doi/pdf/10.1596/0-1952-1601-6

- Ndlozi, M. Q., 2014. Full Speech of Commissar Andile Mngxitama in Response to the Sona in Parliament. Economic Freedom Fighter.

- Nelson, G. and Prilleltensky, I. eds., 2010. Community psychology: In pursuit of liberation and well-being. Palgrave Macmillan. Available online: https://books.google.co.za/books?id=dE8SCwAAQBAJ\&pg=PT548\&lpg=PT548\&dq=For + th e+poor, +the+good+life+or+wellbeing + is + multidimensional + with+both + material +and +ps ychological +dimensions.\&source =bl\&ots =xlzbrVz8oV\&sig=_p-kiNB1qE3082YaUCrT0jtiNo\&hl=en\&sa=X\&ved=0ahUKEwjXtojfgYDOAhUB6RQKHWUoD8wQ6AEIKZAD\#v=onepag e\&q=For\%20the\%20poor\%2C\%20the\%20good\%20life\%20or\%20wellbeing\%20is\%20multidi mensional\%20with\%20both\%20material\%20and\%20psychological\%20dimensions. \&f=false

- Obeng-Odoom, F., 2011. Land Reforms in Africa: Theory, Practice and Outcome. Habitat International. Elsevier Ltd. The University of Sydney, Sydney, Australia.

- Olsen, S.H., Zusman, E., Miyazawa, I., Cadman, T., Yoshida, T. and Bengtsson, M., 2014. Implementing the Sustainable Development Goals (SDGs): An Assessment of the Means of Implementation (MOI). Available online: http://www.iges.or.jp/isap/2014/PDF/IPSS_SDGs_conference_paper.pdf 
- Pepeteka, T., 2013. Reversing the Legacy of the 1913 Natives Land Act: Progress of Land Reform. Research Unit, Parliament of the Republic of South Africa.

- Pringle, E., 2013. Land Reform and White Ownership of Agricultural Land in South Africa. The Journal of the helen Suzman Foundation.

- Provincial Budgets and Expenditure Review. 2010. Chapter 3: Education.

- Ramdass, K. 2009. The challenges facing education in South Africa. University of Johannesburg. Available online: https://ujdigispace.uj.ac.za/bitstream/handle/10210/5397/Kem.pdf? [Accessed on 03 May 2016]

- Richmond, J., 2007. The Measurement of Poverty in South Africa Project: Key Issues. Studies. Available

online: http://www.treasury.gov.za/publications/other/povertyline/SPII\%20document.pdf

- Rogan, M., 2014. Poverty may have declined, but women and female-headed households still suffer most. Econ $3 \times 3$.

- Schwabe, C., 2004. Fact sheet: poverty in South Africa. Human Sciences Research Council, 26.

- Sekhampu, T.J., 2013. Determinants of poverty in a South African township.Journal of Social Sciences, 34(2), pp.145-153. Available online: http://www.krepublishers.com/02Journals/JSS/JSS-34-0-000-13-Web/JSS-34-2-000-13-Abst-PDF/JSS-34-2-145-13-1393Sekhampu-T-J/JSS-34-2-145-13-1393-Sekhampu-T-J-Tx[6].pmd.pdf

- Sharma, S., 1999. April. Land tenure and poverty in Nepal. In WDR-2000 consultation meeting organized by the World Bank. Available online: http://www.rrojasdatabank.info/wpover/sharma.pdf

- Slorstad, J. D., 2010. Impact of land redistribution on consumption in South Africa. An impact assessment analysis of the South African land reform. University of Oslo

- Wachter, F., 2010. An Investigation of The South African Land Reform Process, From A Conflict Resolution Perspective. Nelson Mandela Metropolitan University.

- Wilkinson, K. 2013. Is SA's education system the worst in Africa? Not according to the data. Africa Check: Sorting facts from fiction. Available online: https://africacheck.org/reports/issas-education-system-the-worst-in-africa-not-according-to-the-data/\#comments [accessed on 02 May 2016]

- Woolard, I. 2002. An Overview of Poverty and Inequality in South Africa. Working Paper prepared for DFID (SA). Pretoria: UK Department of International Development. 
- World Bank. 1995. Key Indicators of Poverty in South Africa. Analysis Prepared for the Office of the Reconstruction and Development Program. Pretoria: South African Communication Service.

- World Bank., 1975. Land Reform. Sector Policy Paper. International Development Association.

AUTHORS' CONTACT:

\begin{tabular}{|r|l|}
\hline OBI, Ajuruchukwu & TAFA, Sanelise \\
Dept. of Agricultural Economics \& & Dept. of Agricultural Economics \& \\
University of Fort Hare & Extension \\
Email: aobi@ufh.ac.za & Email: \\
& \\
\end{tabular}

